\title{
Occupational Health Risks and the Worker's Right to Know
}

\author{
The cost of a thing is the amount of what I will call \\ life which is required to be exchanged for it, immediately \\ or in the long run.
}

Henry David Thoreau, Walden

Occupational disease ${ }^{1}$ is a major national health problem; ${ }^{2}$ an estimated 390,000 new cases of occupational illness and 100,000 work-related deaths occur each year. ${ }^{3}$ Occupational exposure to carcinogens may be a factor in more than twenty percent of all cancer cases in the United States. ${ }^{4}$ The health hazards posed by occupational disease are largely hidden from the workers whose health is at risk, and current Occupational Safety and Health Administration (OSHA) ${ }^{5}$ regulations fall far short of

1. An occupational disease is one that results from conditions of employment. Classic examples include respiratory diseases such as asbestosis, which results from inhalation of asbestos fibers, and the liver cancer angiosarcoma, which results from exposure to vinyl chloride.

2. See N. ASHFORD, CRISIS IN THE WORKPLACE: OCCUPATIONAL DISEASE AND INJURY 92-96 (1976) (available statistics seriously underestimate enormity of America's health problem and attendant social costs of hazardous working conditions); U.S. DEP'T OF LABOR, AN INTERIM REPORT TO CONGRESS ON OCCUPATIONAL DISEASES 11-53 (1980) (assessment of magnitude and severity of occupational disease problem). A report issued by a panel of the Center for Disease Control concluded: "Our knowledge of disease and death caused by substances in the workplace, while very incomplete, is sufficient to suggest that we are on the threshold of 'an epidemic' of occupationally related disease." CDC Advisory Group Lists Hazards in Workplace as Top Priority Problem, [1978] OccupaTional SAFETY AND HEALTH REPORTER (BNA) 540 [reporter hereinafter cited as O.S.H. REP.].

3. Report on Occupational Safety and Health by the U.S. Dep't of Health, Education, and Welfare, in THE PRESIDENT'S REPORT ON OCCUPATIONAL SAFETY AND HEALTH 111 (1972). These estimates are probably conservative. See, e.g., D. BERMAN, DEATH ON THE JOB 44-46 (1978) (estimate in The President's Report on Occupational Safety and Health, supra, probably far below true incidence rate, given low recognition and compensation of occupational disease); Note, Compensating Victims of Occupational Disease, 93 HARV. L. REV. 916, 916 n.2 (1980) (finding estimates conservative based on other occupational disease and mortality statistics).

4. Toxic Substances Strategy CommitTee, Toxic Chemicals and Public Protection 120 (1980). The importance of occupational exposure as a cause of cancer is a subject of continuing debate. See, e.g., Number of Job-Induced Cancers Over-Rated, NYU Professor Tells SOCMA, [1979] O.S.H. REP. (BNA) 454 (address by Harry B. Demopoulos at meeting of Synthetic and Organic Chemical Manufacturers Association); Occupational Carcinogens Described as Significant Factor in Cancer Deaths, [1980] O.S.H. REP. 560 (comments of Joel B. Swartz, University of Illinois Medical Center); One-Tenth of U.S. Cancer Deaths in Coming Years Related to Asbestos, [1978] O.S.H. REP. (BNA) 32 (testimony of Irving J. Selikoff, director of Environmental Sciences at Mount Sinai School of Medicine); Smoking, Not Occupation Responsible for Many Cancer Cases, Conference Told, [1980] O.S.H. REP. (BNA) (opinion of Sir Richard Doll, professor of medicine at Oxford).

5. OSHA, a division of the Department of Labor, has primary responsibility for carrying out the duties of the Secretary of Labor under the Occupational Safety and Health Act of 1970, 29 U.S.C. $\$ \S$ $651-78$ (1976). 
requiring adequate disclosure to employees of discoverable health risks. ${ }^{6}$

The health risks of employment should be discovered and disclosed to workers for at least three important reasons: to respect the autonomy of individuals in making basic life decisions, to legitimate the distribution of risk, and to enhance the efficiency of efforts to reduce risk. This Note argues that the common law provides a firm basis for requiring employers to disclose to employees the hidden health risks of employment. In order to standardize the assessment and disclosure of occupational health risks, the Note proposes the enactment of federal legislation modeled after consumer protection disclosure laws.

\section{Occupational Health Risks}

The chronic nature of most of the diseases that result from exposure to toxic substances ${ }^{7}$ makes occupational health hazards difficult to identify and assess. The effects of exposure to toxic substances typically surface several years or more after initial exposure, particularly in the case of carcinogens. ${ }^{8}$ Even a very brief period of exposure to some substances, such as asbestos, may increase significantly the risk of serious disease later in life. ${ }^{9}$ Most of the more than 200,000 chemicals used currently in workplaces $^{10}$ are known to employees only by trade names, and even employers often do not know the chemical compositions ${ }^{11}$ of the many hazardous substances used in their plants. ${ }^{12}$

6. See pp. $1795-98$ infra.

7. For purposes of this Note, a toxic substance is defined as any substance that has a demonstrated potential for impairing health. For a more technical definition of toxicity in the context of workplace exposure, see 46 Fed. Reg. 4412, 4416 (1981) (proposed rule for identification of workplace hazards).

8. Control of Toxic Substances in the Workplace: Hearings Before a Subcomm. of the Comm. on Gov't Operations House of Representatives, 94th Cong., 2d Sess. 3 (1976) (statement of Dr. Thomas F. Mancuso, research professor of occupational health, University of Pittsburgh) [hereinafter cited as Toxic Substances Hearings]. See W. LOWRANCE, OF ACCEPTABLE RISK 69 (1976) (table of latency periods in man for some known carcinogens).

9. See Short-Exposure Risk Indicated in Study of New Jersey Workers, Researcher Says, [1978] O.S.H. REP. (BNA) 102 (report of Herbert Seidman, representative of American Cancer Society).

10. The National Institute for Occupational Safety and Health (NIOSH) has a file of more than 200,000 chemical products. Toxic Substances Hearings, supra note 8 , at 46 (testimony of Dr. John F. Finklea, then director of NIOSH). About 1,000 new chemicals are introduced into the workplace each year. 46 Fed. Reg. 4412,4415 (1981).

NIOSH was created by $\S 22$ of the Occupational Safety and Health Act of 1970,29 U.S.C. $\$ 671$ (1976). It is a part of the Department of Health and Human Services and conducts research and education programs relating to occupational safety and health.

11. NATIONAL INSTITUTE gOR OCCUPATIONAL SAFETY AND HEALTH, THE RIGHT to KNOW 7 (1977) (over $70 \%$ of chemical exposures recorded in health hazards survey attributable to trade name products with chemical compositions unknown to company).

12. Thousands of known toxic substances currently are used commercially, and usually workers are exposed to mixtures of chemicals that may lead to multiple causation of disease or synergistic effects. N. ASHFORD, supra note 2, at 15. 


\section{A. Effects of Insufficient Information}

As a result of poor information regarding the health risks of employment, only a small percentage of the victims of occupational disease receive any compensation for their injuries. ${ }^{13}$ The extended period of time between exposure to hazardous substances and the onset of disability or death, combined with the fact that many occupation-related diseases have multiple causes, makes it difficult to establish the requisite causation for compensation. ${ }^{14}$ Furthermore, because of their ignorance of workplace health hazards, many workers may not recognize occupation-related diseases as such and may not file claims for workers' compensation. ${ }^{15}$

Because of this information deficiency and the limits of current state workers' compensation laws, even workers who receive some compensation for occupation-related diseases are not compensated fully. ${ }^{16}$ Most such workers receive only about one-eighth of their lost wages, ${ }^{17}$ largely because the medical and legal complexities involved in establishing the requisite causation lead to compromised claims and high legal and administrative costs. ${ }^{18}$ Furthermore, even the maximum recovery possible under workers' compensation laws does not include payments for pain and suffering or for other intangible costs of illness or shortened life. ${ }^{19}$

The costs of occupational disease, then, rest largely on employees. Much of the cost that is not borne by employees and their families is paid

13. U.S. DEP'T OF LABOR, supra note 2, at 3 (only five percent of employees severely disabled by occupational disease receive workers' compensation).

14. Id. For a thorough discussion of causation problems and other difficulties in obtaining benefits for occupational disease disability under current state workers' compensation laws, see N. ASHFORD, supra note 2, at 411-16; Note, supra note 3 , at 920-29.

15. See D. BERMAN, supra note 3 , at 68-69. In a two-year pilot project sponsored by NIOSH, workers in 136 small plants in Oregon and Washington were examined for symptoms of work-related disease. The project data showed that nearly $90 \%$ of the work-related medical conditions discovered had not resulted in claims for workers' compensation. Toxic Substances Hearings, supra note 8, at 3940 (testimony of Dr. John Finklea, then director of NIOSH).

Further, though some occupational diseases result only from exposure to a specific substance, many occupational diseases create clinical symptoms indistinguishable from the "ordinary diseases of life." U.S. DEP'T OF LABOR, supra note 2, at 68.

16. To address this problem, a bill introduced in Congress in 1979, Congressional Record, H.R. 5482, 96th Cong., 1st Sess., 125 CONG. REC. H8786 (1979), would have set a minimum federal standard for workers' compensation awards and procedures. See Measure to Set Federal Standards Would Be Inflationary, House Panel Told, [1980] O.S.H. REP. (BNA) 999. A Senate bill introduced in 1980, Congressional Record, S. 2847, 96th Cong., 2d Sess., 126 CoNG. REC. S7286 (1980), would have set minimum standards for compensation of asbestos-related disabilities. Senate Bill Would Set Minimum Standards for Asbestos-Related Compensation Awards, [1980] O.S.H. REP. (BNA) 96.

17. U.S. DEP'T OF LABOR, supra note 2, at 4. But see D. BERMAN, supra note 3, at 62 (those receiving compensation recover average of slightly more than $20 \%$ of income losses from job-related disability).

18. See U.S. DEP'T OF LABOR, supra note 2, at 3-4 (due to medical and legal complexities, $60 \%$ of occupational disease compensation awards initially were denied and over $50 \%$ of occupational disease compensation awards ended in compromise and release agreements involving small lump settlements).

19. See 2A A. LARSON, THE LAW OF WORKMEN'S COMPENSATION $\S 65.20$ (1976). 
by the public in the form of social welfare health benefits. ${ }^{20}$ Employers bear only a small part of the financial burden of occupational health risks, and therefore have insufficient incentive to improve job health. Employers typically will attempt to prevent occupational health hazards only if prevention costs less than their direct costs from occupational illness. Because employers' direct costs, consisting principally of workers' compensation premiums, reflect only a small proportion of the true costs of occupational disease, employer expenditures for prevention are correspondingly low. ${ }^{21}$

The lack of information about workplace hazards also impedes efforts to reduce health risks through collective bargaining. Some labor unions, notably the Oil, Chemical and Atomic Workers, the United Auto Workers, and the United Steel Workers, have bargained successfully for increased information about health risks. ${ }^{22}$ The bargaining energy and resources required to obtain information about risks, however, detract from the ability of unions to bargain for the actual reduction of risks. Better information is essential to any attempt to reduce the insidious risks of occupational disease. ${ }^{23}$

\section{B. Current Approaches to the Information Problem}

Federal regulation of workplace health has relied on standards for specific substances and has failed to address adequately the general information problem. Recent state legislative efforts to fill the information gap, though significant, are inherently limited.

\section{1. $O S H A$}

Federal efforts to reduce health risks from exposure to toxic substances in the workplace have focused on setting maximum exposure standards for specific substances under section $6(b)(5)$ of the Occupational Safety and Health Act. ${ }^{24}$ In addition, section $6(\mathrm{~b})(7)$ of the Act mandates warnings to

20. Id. at 4 (occupational disease costs the social security and welfare systems about $\$ 2.2$ billion annually).

21. See N. ASHFORD, supra note 2, at 346-53 (most serious obstacle to improvement in workplace health and safety is failure to hold employers financially accountable for consequences of hazardous working conditions).

22. See N. ASHFORD, supra note 2, at 492-95; L. BACOW, BARGAINING FOR JOB SAFETY AND HEALTH 61-76 (1980); D. BERMAN, supra note 3, at 120-30. Access to such information has also been won through litigation under the National Labor Relations Act. See pp. 1805-06 infra.

23. According to Anthony Robbins, Director of NIOSH: "Perhaps the greatest problem facing cccupational health practitioners is the "ignorance of employers and workers about exposures to toxic substances . . . . The most rapid way to bring about change in occupational medicine would be to inform workers.' "Ignorance" About Exposures Seen Greatest Occupational Health Problem, [1979] O.S.H. REP. (BNA) 517 (address to American Medical Association Congress on Occupational Health).

24. 29 U.S.C. $\$ \S 651-78$ (1976). Section 6(b)(5) provides:

The Secretary, in promulgating standards dealing with toxic materials or harmful physical 
employees about the hazards of substances for which an exposure standard has been set. ${ }^{25}$ Under this warning provision, some OSHA standards require signs on the entrances to areas in which the regulated substance is used and labels on containers holding the regulated substance. The required warnings and labels are of a general cautionary nature, however, and do not define specifically the dangers posed. ${ }^{26}$

OSHA's warning requirements are inadequate even for the few substances presently regulated. ${ }^{27}$ The requirements fail to mandate assessment of exposures and health risks on a job-position basis and do not require warnings to individuals offered hazardous jobs. Furthermore, OSHA has set standards for only a small share of the large number of workplace substances known to have serious health effects, ${ }^{28}$ and it has

agents under this subsection, shall set the standard which most adequately assures, to the extent feasible, on the basis of the best available evidence, that no employee will suffer material impairment of health or functional capacity even if such employee has regular exposure to the hazard dealt with by such standard for the period of his working life.

29 U.S.G. $\S 655(\mathrm{~b})(5)(1976)$.

25. 29 U.S.C. $\S 655(b)(7)(1976)$.

26. For example, containers of the carcinogen vinyl chloride are required to bear the label: "POLYVINYL CHLORIDE (OR TRADE NAME) / Contains / VINYL ChLORIDE / VINYL CHLORIDE IS A CANCER-SUSPECT AGENT.” 29 C.F.R. $§ 1910.1017(1)(4)$ (1980). Similarly, entrances to areas in which asbestos fibers may exceed exposure limits must be posted with a sign that bears the statement: "CAU. TION / Contains Asbestos Fibers /Avoid Creating Dust / Breathing Asbestos Dust May Cause Serious Bodily Harm." 29 C.F.R. § 1910.1001(g)(2) (1980).

Some regulations setting maximum exposure limits for a substance also require employers to notify employees known to have been exposed to concentrations in excess of the exposure limit. Sec, e.g., 29 C.F.R. § 1910.1001(i)(3) (1980) (notification requirements with respect to asbestos, promulgated in 1974). Other regulations require training for employees who will come into contact with the regulated substance. See, e.g., 29 C.F.R. \$ 1910.1017(j) (1980) (training requirements for handling vinyl chloride, promulgated in 1974).

27. See NATIONAL INSTITUTE FOR OCCUPATIONAL SAFETY AND HEALTH, supra note 11, at 5 (finding workers unaware of wide variety of potentially harmful chemical agents to which they are exposed). A survey of occupational hazards conducted by NIOSH in 1976 found minimal workplace recognition of OSHA regulated substances. In the 5,200 plants surveyed, workers were exposed to 95,000 different trade name products. The actual chemical composition of $90 \%$ of those products was unknown at the plants where they were used. Of the 40,592 trade-name products that NIOSH subsequently identified, 17,987 or approximately $45 \%$ contained chemicals regulated by OSHA. Toxic Substances Hearings, supra note 87, at 55-56 (letter of Dr. John F. Finklea, director of NIOSH).

28. The Registry of Toxic Effects of Chemical Substances, a document prepared and updated by NIOSH pursuant to $\S 20(a)(6)$ of the Occupational Safety and Health Act, 29 U.S.C. $\S 669(a)(6)$ (1976), listed 33,929 toxic substances in 1978; about 1,500 new toxic substances are added to the Registry each quarter. 45 Fed. Reg. 35,212, 35,258 (1980) (to be codified in revised 29 C.F.R. \$ 1910.20). A sub-file of suspected carcinogens lists nearly 2,000 substances. NATIONAL INSTITUTE FOR OCCUPATIONAL SAFETY AND HEALTH, supra note 11, at 9.

OSHA has converted pre-OSHA advisory health standards for approximately 400 toxic substances into legally enforceable exposure limits. U.S. DEP'T OF LABOR, supra note 2, at 111; see 29 C.F.R. § 1910.1000 (1980) (regulation of air contaminants). Since the passage of the Occupational Safety and Health Act in 1970, NIOSH has supplied OSHA with "criteria documents," recommending further regulation of some 90 substances or categories of substances. 45 Fed. Reg. 35,212, 35,258 (1980). Such criteria documents are authorized by $\S 22(c)(1)$ of the Act, 29 U.S.C. $\S 671$ (c)(1) (1976). Yet OSHA has issued only 11 new health standards covering 23 substances. U.S. DEP'T OF LABOR, supra note 2 , at 111 . 
inadequate resources to enforce even those standards effectively. ${ }^{29}$ Current procedures and resources will permit regulation of only a very small percentage of toxic workplace chemicals in the foreseeable future. ${ }^{30}$

Recently, OSHA has undertaken information initiatives apart from the standard-setting process. A recently enacted rule grants employees and their representatives access to employer records of employee exposure to toxic substances and employee medical data. ${ }^{31}$ The preamble to the OSHA access rule expresses the importance of the employee's "right to know,",32 but the rule falls short of establishing that right. The rule does not mandate the keeping of any records; it only creates rights of access to existing records and requires their preservation. ${ }^{33}$ Yet only a small minority of employers monitor employee exposure to toxic substances, ${ }^{34}$ and regular monitoring generally is not required even for substances subject to official OSHA exposure standards. ${ }^{35}$ Moreover, the rule will actually deter employers from maintaining exposure records that are not required; by pro-

29. Although approximately 25 million workers, one-fourth of the United States labor force, may be exposed to OSHA-regulated health hazards, only 500,000 workers are employed in worksites inspected by OSHA in a given year. U.S. DEP'T OF LABOR, supra note 2, at 112-14. OSHA has approximately 1,500 inspectors to enforce all OSHA workplace requirements. 46 Fed. Reg. 4412,4432 (1981). Further, the present level of OSHA enforcement does not create any financial incentive for compliance with OSHA standards. See Viscusi, The Impact of Occupational Safety and Health Regulation, 10 BELL J. OF ECON. 117 (1979). There is no private right of action to enforce the Occupational Safety and Health Act or regulations made pursuant to it. See Russel v. Bartley, 439 F.2d 334 (6th Cir. 1974) (Occupational Safety and Health Act does not create private right of action against employers found guilty of violating Act); Skidmore v. Travelers Ins. Co., 438 F.2d 67 (5th Cir. 1973) (same); Blessing v. United States, 447 F. Supp. 1160 (D. Pa. 1978) (same).

30. 45 Fed. Reg. 35,212, 35,258 (1980). The standard-setting process is long and costly. See U.S. DEP'T OF LABOR, supra note 2, at 112. It involves an initial NIOSH criteria document recommending regulation of a substance, advance notice of proposed rulemaking, public comment and hearings, publication of a proposed rule, further public comment and hearings, and promulgation of a final rule subject to judicial review. The procedures for standard setting are prescribed by $\S 6(\mathrm{~b})$ of the Occupational Safety and Health Act, 29 U.S.C. $\$ 655(\mathrm{~b})(1976)$. Judicial review is specifically provided for in $\S 6(f), 29$ U.S.C. $\S 655(f)$ (1976). All but two of the health standards issued by OSHA have been challenged in the courts, and thus enforcement has usually been stayed or limited pending final court decisions. U.S. DEP'T OF LABOR, supra note 2, at 112. OSHA officials have estimated that in the future it will take three and one-half to four years to issue a major standard after receiving a criteria document. NIOSH Eyes Increase in Fjeld Efforts by Shifting Positions, NACOSH is Told, [1979] O.S.H. REP. (BNA) 380; cf. Slowdown in Rate of OSHA Standards Seen Result of Supreme Court Ruling, [1980] O.S.H. REP. (BNA) 263 (predicting Supreme Court decision on benzene standard will slow issuance of regulations).

31. 45 Fed. Reg. 35,212 (1980).

32. "Workers must, in all cases, at least have a right to know exactly what they are exposed to on the job, what is the magnitude of this exposure, and what are the resulting adverse health effects." Id. at 35,239 .

33. Id. at 35,253 .

34. Only $22 \%$ of industrial employees work in plants in which monitoring is regularly performed; even in the chemical industry, environmental conditions are regularly monitored in only $21 \%$ of the plants. Id. at 35,255 .

35. In most cases continued monitoring is required only if initial monitoring reveals exposure in excess of the permissible limit. See, e.g., 29 C.F.R. $\S 1910.1017$ (d) (1980) (monitoring requirements for vinyl chloride); 29 C.F.R. \& 1910.1018(c) (monitoring requirements for inorganic arsenic); 29 C.F.R. $\$ 1910.1025$ (d) (monitoring requirments for lead). 
viding additional information for workers' compensation claims and collective bargaining demands, employers maintaining such records would be disadvantaged competitively. ${ }^{36}$

Another OSHA information initiative has been even less successful. OSHA proposed a chemical labeling standard on January $16,1981,{ }^{37}$ but withdrew it on February 12, 1981. ${ }^{38}$ The proposed standard would not have required comprehensive health risk information, but only general cautionary labels on chemicals declared hazardous by the manufacturer or importer. ${ }^{39}$

\section{State Legislation}

To fill the gap created by inadequate federal regulation, at least five states recently have enacted laws aimed at informing employees about occupational health risks. ${ }^{40}$ With varying degrees of comprehensiveness, each law requires employers to discover and to disclose to employees relevant health risk information. New York's law ${ }^{41}$ is perhaps the most comprehensive. It requires employers to obtain certain information relating to toxic substances ${ }^{42}$ from the manufacturer and various named government

36. 45 Fed. Reg. 35,212, 35,236 (1980).

37. 46 Fed. Reg. 4412 (1981). The proposed standard was published by OSHA some seven years after receiving a NIOSH criteria document recommending a standard for identification of occupational hazards. Id. at 4416.

38. 46 Fed. Reg. 12,020 (1981). Withdrawal of the proposed standard was one of the first acts in office by President Reagan's Secretary of Labor, Raymond Donovan. See Swift Attack on Regulations, N.Y. Times, Feb. 13, 1981, $\S$ A, at 15, col. 1 (new Secretary of Labor serves notice he will not be slow to carry out Reagan's mandate to ease regulatory burden on business).

39. As proposed, the rule would have required manufacturers and importers to identify and evaluate hazardous substances according to prescribed procedures. 46 Fed. Reg. 4412,4442 (1981). Covered employers would have been required to ensure that containers of hazardous substances were labeled by common name and Chemical Abstracts Service identification number and were identified by a prescribed hazard warning label. Id. at 4443 .

Hazards would have been separated into two major categories: A for physical hazards and B for acute or chronic health hazards. Category B contained eight classes of health hazards, each with a prescribed statement of hazard that would have gone on the label of each substance in the class. For example, a label on a container holding a carcinogenic substance would have borne the statement, "Danger: May cause cancer"; a container holding a substance that was toxic on inhalation would have borne the statement, "Warning, Toxic: May be fatal if inhaled"; and a container bearing a substance judged to be an eye irritant would have borne the statement, "Warning, Irritant: Causes eye irritation." See id. at 4412, 4452.

40. See 1980 Cal. Stats. 2961 (to be codified in Gal. LAB. CODE $\$ \S 6360-99$ ); 1980 Conn. Pub. Acts, P.A. No. 80-257; ME. REV. STAT. ANN. tit. 26, § 1701 (1980); 1980 Mich. Pub. Acts, P.A. 51; 1980 N.Y. Laws 892 (to be codified in N.Y. LAB. LAW § 875); cf. 46 Fed. Reg. 4412, 4422-23 (summary of state statutes and regulations requiring some form of labeling on chemicals in work place).

41. 1980 N.Y. Laws 892 (to be codified in N.Y. LAB. LAW $§ 875$ ) (effective January 1981).

42. New York defines a "toxic substance" as any substance that is listed in the latest printed edition of NIOSH's Registry of Toxic Effects of Chemical Substances, discussed at note 28 supra, or that "has yielded positive evidence of acute or chronic health hazards in human, animal or other biological testing." 1980 N.Y. Laws 892,892 (to be codified in N.Y. LAB. LAW $\$ 875(2)$ ). 
sources, ${ }^{43}$ to make that information available to employees, ${ }^{44}$ and to provide education and training to employees routinely exposed to such substances. ${ }^{45}$ Failure to comply with the New York law exposes the employer to civil and criminal penalties, ${ }^{46}$ but neither it nor any of the other state laws creates a private right of action for affected employees.

Thus, even the more ambitious current statutory approaches fall substantially short of achieving the policy objectives underlying the employee's right to know. They do not provide for standardized evaluation and disclosure of health risks and therefore do not allow comparisons among different workplaces and job positions. Their effectiveness is limited by the inadequate and unsystematic information now available to employers, and by the failure to provide a private right of action for workers. Moreover, as with any series of state-by-state remedies, these laws cannot take advantage of economies of scale in the production of health-risk information. ${ }^{47}$

\section{A Normative Case for the Right to Know}

All employees should have the right to receive information about the discoverable health risks of their employment. The allocation and distribution of health risks from industrial production can be justified only if such disclosure is made. Full disclosure is essential to the protection of individual autonomy in making basic life decisions and to the efficient reduction of risks.

\section{A. Legitimating the Distribution of Risk and Respecting Individual Autonomy}

American society endures an uncertain, but large amount of health impairment and increased mortality in order to maintain industrial production. ${ }^{48}$ Public decisionmaking has concentrated on controlling the magnitude of that risk, rather than on distributing the risk equitably. A disproportionate share of the health costs from the use of industrial toxics falls upon industrial workers and their families. ${ }^{49}$ The statistical risk of

43. Id. at 893 .

44. Id.

45. Education and training programs are to be provided prior to initial work assignment and annually thereafter. Id. at 894.

46. Failure to comply can result in a civil penalty of up to $\$ 10,000$. Willful violation is a misdemeanor for which a first offense is punishable by a fine of up to $\$ 500$ and imprisonment for up to 30 days. Id. at 896.

47. Cf. p. 1809 infra (discussion of government's role in producing health risk information).

48. See p. 1792 supra.

49. See pp. 1794-95 supra. In addition to loss of support and companionship, families of industrial workers may face a direct health risk. See Commoner, Workplace Burden, ENVIRONMENT July/ Aug. 1973, at 15, 19 (families exposed to asbestos carried home on the clothes and shoes of workers); 
cancer for workers in certain industries is much greater than that for the general population. ${ }^{50}$ Regulatory standards permit much higher levels of exposure to toxic substances within the workplace than outside of it. ${ }^{51}$ Case histories reveal strikingly less popular concern and less effective government intervention when hazardous conditions are discovered in the workplace than when they are found in the general environment. ${ }^{52}$

The disproportionate share of health risks borne by industrial workers would be more equitable and acceptable if the risks were knowingly encountered and adequately compensated..$^{53}$ Without full knowledge of the hidden but discoverable health risks that result from exposure to toxic substances, workers cannot be said to have accepted the risks voluntarily. ${ }^{54}$

Asbestos Researcher Criticizes Lack of Tumor Monitoring, Family Evaluation, [1979] O.S.H. REP. (BNA) 360 (same).

50. See, e.g., L. AgRAN, The CanGer Connection 24-25 (1977) (lung cancer accounts for 50\% of all deaths among uranium workers; $94 \%$ of dyestuff workers exposed to benzidine and betaNapthylamine for five years or more developed bladder tumors); U.S. DEP'T OF LABOR, supra note 2, at 11-38 (statistics showing high rate of cancer in certain industries); Excess Proportion of Cancer Deaths Among Woodworkers Reported by NIOSH, [1980] O.S.H. REP. (BNA) 951 (March 13, 1980); Government Studies Indicate Excesses in Cancers; Industry Challenges Reports, [1980] O.S.H. REP. (BNA) 573 (elevated risk of brain cancer among petro-chemical workers); UAW Study Finds Excess Lung Cancer Among Workers at GM Hardware Plant, [1980] O.S.H. REP. (BNA) 480.

51. OSHA standards for maximum exposures to airborne pollutants in the workplace generally exceed Environmental Protection Agency (EPA) standards for the general environment by 10 to 100 times. See W. LOWRANCE, supra note 8, at 90-91; Commoner, supra note 49, at 19.

Comparison of jointly regulated carcinogens reveals similar discrepancies. For example, the permissible workplace exposure level for vinyl chloride is one ppm averaged over an eight hour period with a ceiling exposure of five $\mathrm{ppm}$ averaged over any fifteen minute period. 29 C.F.R. $\$ 1910.1017$ (c) (1980). By contrast, the Consumer Product Safety Commission has banned from household use products that contain any vinyl chloride, because they "possess such a degree or nature of hazard that adequate cautionary labeling cannot be written and the public health and safety can be served only by keeping such articles out of interstate commerce." 16 C.F.R. $\$ 1500.17(a)(10)$ (1980). Products containing respirable free-form asbestos also are banned. See 16 C.F.R. $\$ 1500.17$ (a)(7) (1980) (banning general use garments containing asbestos). By contrast, OSHA standards permit significant exposure to asbestos-up to a limit of five fibers longer than five micrometers per cubic $\mathrm{cm}$ of air on the average over eight hours-and set a ceiling exposure limit of ten fibers. 29 C.F.R. $\$ 1910.1001$ (a) (1980).

52. Workplace evidence of the health hazards of polychlorinated biphenyls (PCBs), a widely-used class of synthetic organic substances, has existed for many years but largely has been ignored; yet discovery of PCBs in the general environment has led to a great deal of scientific and public concern. See Commoner, supra note 49, at 17-18. PCBs are now regulated by the EPA under $\S 307$ of the Federal Water Pollution Control Act, 40 C.F.R. $\S 129.105$ (b) (1980) (PCBs prohibited in effluent discharge). There is no workplace standard for PCBs.

The contrast in public response to environmental as opposed to occupational toxic exposures is demonstrated by the justifiably intense media coverage and political fervor over the dumping of hazardous wastes. See, e.g., The Neighborhood of Fear, TiME, June 2, 1980, at 61 (Love Canal hazardous waste dumpsite in New York); Nuclear Nightmare, TIME, Apr. 9, 1979, at 8 (accident at Three Mile Island nuclear plant outside of Harrisburg, Pennsylvania). Discoveries that worker populations have been exposed to the same substances have failed to generate similar responses.

53. Cf. W. LOWRANCE, supra note 8 , at 87-88 (risks more acceptable when voluntary).

54. It might be argued that with limited worker mobility, especially in times of high unemployment, the acceptance of workplace risk is not voluntary even if the risk is known. "Poor people, on the average, will be willing to accept risky work for lower compensation than higher-income individuals would demand." Nichols \& Zeckhauser, Government Comes to the Workplace: An Assessment of OSHA, 49 PUB. INTEREST, Fall 1977, at 39, 46. This Note does not contend that disclosure of risk is sufficient to protect workers with limited bargaining power, that OSHA should not continue to set 
The decision to undertake dangerous work in exchange for compensation is a basic life decision concerning employment, personal health care, and often the support of one's family. A free society respects individual autonomy in those three areas of vital personal interest..$^{55}$ Only the affected individual can judge whether the compensation offered offsets the resulting health risk. If the extent of the health risk posed by the work is hidden from the potential employee, his or her freedom to make this decision is impaired.

The individual's right to decide whether to undertake dangerous work should be safeguarded to the same extent as other basic life decisions. As consumer transactions law has recognized by disclosure laws that protect the consumer's safety and economic interests, ${ }^{56}$ choice is not free unless it is informed. Workers should have the right to know the risks they may encounter when they accept employment. ${ }^{57}$

\section{B. Enhancing the Efficiency of Risk Reduction}

Health risks entail serious potential costs for employees and their families: medical expenses and lost wages that are not covered by workers' compensation, $^{58}$ and the intangible costs of pain and suffering that may

maximum exposure standards, or that OSHA's lengthy procedures should not be streamlined. In the case of some organized workers, however, bargaining power may be substantial; if any choice exists, risks should be disclosed.

55. Our society has long respected an individual's freedom of choice in the conduct of his or her own affairs. Even before the framing of the Constitution, the common law recognized the importance of freedom of choice in basic life decisions such as those concerning marriage, procreation, employment, education, domicile, and personal health care. Cf., e.g., Meyer v. Nebraska, 262 U.S. 390,399 (1923) (defining "liberty" for purposes of Fourteenth Amendment in terms of "those privileges long recognized at common law as essential to the orderly pursuit of happiness by free men," including rights to contract, to engage in common occupations of life, to marry, to establish home and bring up children, to educate oneself); Corfield v. Coryell, 6 F. Cas. 546, 551 (C.C.E.D.Pa. 1823) (No. 3,230) (defining "privileges and immunities" in terms of those "which belong, of right, to the citizens of all free governments"). See generally I. KANT, THE PHILOSOPHY OF LAW 61-158 (W. Hastie trans. 1887) (principles of personal rights).

Our courts have protected against infringement the freedom of individuals to make basic life decisions except when the infringement is justified by a compelling state interest. See, e.g., Doe v. Bolton, 410 U.S. 179, 211-13 (1973) (Douglas, J. concurring) (reviewing Court decisions protecting right to make basic life decisions and freedom to care for one's health and person); Loving v. Virginia, 388 U.S. 1 (1967) (right to marry person of one's own choosing); Griswold v. Connecticut, 381 U.S. 479 (1965) (right to privacy in marital relations); Skinner v. Oklahoma, 316 U.S. 535 (1942) (right of procreation); Pierce v. Society of Sisters, 268 U.S. 510 (1925) (right to direct education of one's children).

Civil rights laws protect individual free choice against private sector coercion in employment, travel, housing, and access to publicly offered accomodations and services. See Civil Rights Act of 1964, 42 U.S.C. $\S 2000 \mathrm{a}$ (access to publicly offered accomodations); $\S 2000 \mathrm{~b}$ (access to public facilities); $\S$ 2000 e (equal employment opportunities).

56. See pp. 1805-06 infra.

57. Cf. 'Endangerment' Would Be Felony Offense Under Bill Approved by Senate Panel, [1979] O.S.H. REP. (BNA) 663 (Senate bill creating federal felony offense for violations of Occupational Safety and Health Act that place others in danger).

58. Some of the costs of occupational disease are not borne by the employer or the employee but 
accompany illness and premature death. The extra compensation that a worker may demand for encountering health and safety risks has been called a "risk premium" or "wage premium". 59

The exaction of risk premiums by employees facing workplace hazards creates an incentive for employers to reduce health risks and thereby to reduce wage costs. In a perfectly competitive labor market, with perfect information and worker mobility, workers' employment decisions would generate compensation appropriate to the level of risk encountered in the workplace. If the extra pay demanded by employees for encountering a risk was greater than the cost of eliminating the risk, the employer would choose the latter. Thus, by minimizing the sum of the cost of preventing accidents and illnesses and the cost of risk premiums for hazardous work, the employer would accept a level of workplace risk identical to that which the workers would accept if they owned the firm. ${ }^{60}$ Hazardous conditions would continue only when workers valued more highly the economic gain from encountering the hazard than freedom from the risk.

Full disclosure of discoverable health risks would enhance the accuracy of risk premiums in reflecting the uncompensated costs of occupational disease and thus would create greater incentive for cost-effective expenditures to reduce health risks. ${ }^{61}$ This would occur to some extent as the result of aggregate risk premium demand whether or not workers are in a position to bargain explicitly and collectively about health risks. ${ }^{62}$ In the case of organized workers, assessment of health risks on a workplace-byworkplace and position-by-position basis would lead to conscious and in- formed collective bargaining for higher wages, reduction of risks, or both. ${ }^{63}$ Thus collective bargaining could become a powerful mechanism for

by the general public as social welfare health benefits. See note 20 supra. These "externalities", costs of production that escape the price system, see R. HEILBRONER, THE ECONOMIC PROBLEM 570-71 (3d ed. 1972), also reduce the employer's incentive to make occupational health expenditures. See Nichols \& Zeckhauser, supra note 54 , at 44.

59. Several recent studies have found empirical evidence of risk premiums; such premiums have long been a part of economists' constructs of labor market behavior. See, e.g., M. BAILEY, REDUCING RISKS TO LIFE 35-47 (1980) (reviewing several studies and their application to estimating the value of a life); R. SMITH, THE OCCUPATIONAL SAFETY AND HEALTH ACT 28-30 (1976); Nichols \& Zeckhauser, supra note 54 , at 42-43.

60. Nichols \& Zeckhauser, supra note 54, at $42-43$.

61. Studies demonstrating the existence of risk premiums, see note 59 supra, do not measure their accuracy but only indicate that "workers are at least partially aware of the risks they run, and that, as economic theory predicts, market forces do lead to higher wages for workers in risky professions." Nichols \& Zeckhauser, supra note 54, at 43.

62. Studies have found both occupation-specific and industry-wide risk premiums without regard to whether workers are organized. See R. SMITH, supra note 59, at 30. Because some unions have been able to acquire information about health risks through the bargaining process, see p. 1795 supra, it could be expected that awareness of health risks is lower among unorganized workers. Mandated disclosure by all employers might, therefore, have an even greater impact upon risk premiums in the case of unorganized workers.

63. It is sometimes suggested that workers inevitably will undervalue health costs expected only in 
regulating occupational health. ${ }^{64}$

\section{The Common Law Right to Know}

The right of workers to know the hidden health risks of employment does not depend upon statutory or regulatory innovation. The common law provides a basis for equitable and injunctive relief to cure the shortcomings of current statutory and regulatory approaches. The employer's duty to warn and the worker's corresponding right to know are reinforced by similar rights of bargaining units under the National Labor Relations Act $^{65}$ and by analogous developments in the field of consumer transactions.

\section{A. The Employer's Common Law Duty}

It is well-established under common law that an employer has a general duty to provide employees with a reasonably safe place to work ${ }^{66}$ to identify latent or concealed dangers discoverable in the excercise of reasonable care, ${ }^{67}$ and to make such dangers known to the employee. ${ }^{68}$ This

the statistical future, and that they will inappropriately subordinate concerns about working conditions to concerns about higher wages. There is evidence that such a tendency, if it existed in the past, is less prevalent today. See D. BERMAN, supra note 3 , at 117 ; S. EPSTEIN, THE POLITICS OF CANCER 437 (1979) (citing 1970 University of Michigan survey finding that American workers rate health and safety as a higher priority than increased wages); cf. 45 Fed. Reg. 35,212, 35,220 (1980) (testimony describing how a local union bargained for control of asbestos exposure); UAW Head Announces Plan to Remove Carcinogens from Automotive Plants, [1980] O.S.H. REP. (BNA) 1092 (describing worker initiative to identify and remove workplace health risks); Assistant Labor Secretary Bingham Speaks of More Coordinated Effort, [1979] O.S.H. REP. (BNA) 103 (predicting workers will no longer trade safety and health for paycheck).

64. [U] nions may be a convenient vehicle for achieving job safety and health objectives. Collective bargaining agreements produce flexible rules governing work conditions that are tailored to meet the needs of the individual firm, that reflect the preferences of the parties, that consider costs of implementation, and that are cost-effective. More important is the fact that the rules are enforced.

L. BACOW, supra note 22 , at 57-58.

65. 29 U.S.C. $\S \S 151-68$ (1976).

66. Sec, e.g., Foreman v. Dorsey Trailers, Inc., 256 Ala. 253, 54 So. $2 d 499$ (1951) (employer liable for failure to provide proper ventilation resulting in lead poisoning); Brown v. Sharphouser Contracting Co., 159 Cal. 89, 112 P. 874 (1910) (employer liable for failure to prevent earth cave-in); Nichols v. Harvey Hubbel, Inc., 92 Conn. 611, 103 A. 835 (1918) (employer liable for negligent design of structure upon which plaintiff was required to work).

67. See, e.g., Rio Grande S. R.R. v. Campbell, 65 Colo. 217, 176 P. 275 (1918) (duty to discover defects in tools); Ft. Smith \& W.R.R. v. Holcombe, 59 Okla. 54, 158 P. 633 (1916) (same); Lemon v. Lonker, $97 \mathrm{~Pa}$. Super. Ct. 240 (1929) (duty to warn domestic servant of defective step ladder that was not obviously defective). But see, e.g., Sample v. Schwenck, 243 Iowa 1189, 54 N.W.2d 527 (1952) (employer not liable for injury from collapse of granary that reasonably prudent person could not have anticipated); Purdy v. Westinghouse Elec. \& Mfg. Co., 197 Pa. 257, 47 A. 237 (1900) (employer not liable because no reason to know that second-hand barrels used to hold castings were explosive).

68. Sec, e.g., Tedford v. Los Angeles Elec. Co., 134 Cal. 76, 66 P. 76 (1901) (employer negligent in failing to warn of hidden danger in handling wires); Hume v. Fort Halifax Power Co., $106 \mathrm{Me}$. 78, 75 A. 300 (1909) (employer negligent in failing to warn of risk of construction rock slide); Clayton v. Ainsworth, 122 N.J.L. 160, 4 A.2d 274 (1939) (employer negligent in failing to warn of danger of falling coal). 
general duty includes the obligation to warn employees of discoverable dangers of occupational disease. ${ }^{69}$ The common law imputes to the employer not only a knowledge of the constituents and general characteristics of the substances used in his or her business, but also a scientific understanding of their risks. ${ }^{70}$

The common law tort most frequently invoked to recover damages for occupational disease was failure to warn. ${ }^{71}$ That tort has become much less important with the advent of strict liability under workers' compensation laws; ${ }^{72}$ nonetheless, and especially in light of the highly uncertain and incomplete compensation for occupational disease, equitable enforcement of the employer's duty to warn still is needed to legitimate risk distribution, to respect individual autonomy, and to reduce risk efficiently.

In Shimp v. New Jersey Bell Telephone Co. ${ }^{73}$ the court enforced the similar common law right of an employee to a safe working environment ${ }^{74}$ holding that the Occupational Safety and Health Act did not pre-

69. See, e.g., Galeota v. U.S. Gypsum Co., 123 F.2d 947 (2d Cir. 1941), cert. denied, 315 U.S. 813 (1942) (employer under duty to instruct day laborer that inhalation of silica dust might result in serious harm); Pigeon v. W.P. Fuller \& Co., 156 Cal. 691, 105 P. 976 (1909) (employer required to warn of possible lead poisoning from fume inhalation even if utmost care taken to reduce danger); Wiseman v. Carter White Lead Co., 100 Neb. 584, 160 N.W. 985 (1916) (employer's duty to warn of danger of lead poisoning not fully satisfied by providing employee with mask to minimize danger); Davis v. New Jersey Zinc Co., 116 N.J.L. 103, 182 A. 850 (1936) (employer negligent for failure to know and warn of danger of manganese poisoning and for failure to take reasonable precautions); Bohlen, The Common Law Right of Action for Occupational Disease in Pennsylvania, 63 U. PA. L. REV. 183 (1915) (employer under duty to warn of occupational disease risk when employer's knowledge of risk superior to that employee could reasonably be expected to have). But see McCreery $v$. Libby-Owens Ford Glass Co., 363 Ill. 321, 2 N.E.2d 290 (1936) (finding no common law precedent for duty to furnish healthful place to work and denying worker in glass factory recovery for pneumoconiosis and tuberculosis); Ewers v. Buckeye Clay Pot Co., 29 Ohio App. 396, 163 N.E. 577 (1928) (denying recovery notwithstanding employer's alleged negligence for failure to warn of danger of "potter's consumption" from dust inhalation).

70. See, e.g., Gentry v. Swann Chem. Co., 234 Ala. 313, 174 So. 530 (1937) (employer obligated to know and acquaint employee with dangers from working in unventilated room with dust fumes and chemical particles); Adams v. Grand Rapids Refrigerator Co., 160 Mich. 590, 125 N.W. 724 (1910) (employer charged with knowledge of chemical changes in enamel manufacture and found negligent for failure to inform employee of danger of explosion); Harvey v. Welch, 86 N.H. 72, 163 A. 417 (1932) (service station operator liable for employee's poisoning despite ignorance of the effects of oxalic acid fumes); Mid-Continent Petroleum Corp. v. Jamison, 197 Okla. 387, 171 P.2d 976 (1946) (employer liable for failure to warn inexperienced employee of fatal sulphur dioxide fumes, even though no previous deaths had resulted from exposure to those fumes).

71. Annot., 105 A.L.R. 80, 96 (1936).

72. Workers' compensation generally has become the injured worker's exclusive remedy against his or her employer. Weisgall, Product Liability in the Workplace: The Effect of Workers' Compensation on the Rights and Liabilities of Third Parties, 1977 WIS. L. REV. 1035, 1039. Recently, however, the California Supreme Court held that a worker disabled by asbestos exposure could sue his employer outside the workers' compensation system for aggravation of the disease caused by the cmployer's fraudulent concealment of the condition and its cause. Johns-Manville Prods. Corp. v. Contra Costa Superior Court, 27 Cal.3d 465, 612 P.2d 948, 165 Cal. Rptr. 858 (1980).

73. 145 N.J. Super. 516, 368 A.2d 408 (1976). See 30 U. VAND. L. REV. 1074 (1977) (discussing Shimp and approving result).

74. The plaintiff, a telephone company secretary allergic to cigarette smoke, successfully sought an injunction requiring her employer to enact an on-the-job smoking ban. 
empt state legislative or judicial action in the field of occupational safety and health. ${ }^{75}$ By distinguishing worker protection from worker compensation, the Court found that the exclusive damages remedy provided by the state workers' compensation law did not preclude injunctive relief. ${ }^{76}$

Because the employer's duty to warn of occupational hazards has a protective as well as a compensatory purpose, ${ }^{77}$ equitable relief is similarly appropriate. Developments in statutory labor law and in the field of consumer transactions subsequent to the development of the common law of warning have further emphasized the independent protective function of disclosure apart from any right to damages. These developments also help define the nature and scope of the common law duty to disclose discoverable occupational hazards in the context of modern, multi-chemical industrial environments.

\section{B. The Right to Know in Labor Law and Consumer Transactions}

Statutes are sources of common law and exert an influence on its development. ${ }^{78}$ The Occupational Safety and Health Act ${ }^{79}$ embodies a recognition that liability rules are not sufficient to encourage adequate protection of health and safety in the workplace and emphasizes prevention rather than compensation. ${ }^{80}$ Arbitration hearings and administrative decisions of the National Labor Relations Board (NLRB) occasionally have established the right of employee representatives to receive information about health risks under the National Labor Relations Act on the grounds that the information is required for informed collective bargaining. ${ }^{81}$ Under

75. 145 N.J. Super. 522, 368 A.2d 408, 410-11 (Ch. Div. 1976). The court relied on $\S 4(b)(4)$ of the Occupational Safety and Health Act, 29 U.S.C. $\$ 653($ b)(4) (1976), which states:

Nothing in this chapter shall be construed to supersede or in any manner affect any workmen's compensation law or to enlarge or diminish or affect in any other manner the common law or statutory rights, duties, or liabilities of employers and employees under any law with respect to injuries, diseases, or death of employees arising out of, or-in the course of, employment.

76. 145 N.J. Super. 515, 524, 368 A.2d 408, 412 (Ch. Div. 1976); see Blumrosen, Ackerman, Kligerman, Van Schaick \& Sheehy, Injunctions Against Occupational Hazards: The Right to Work Under Safe Conditions, 64 CAL. L. REV. 702 (1976) (arguing that private actions by employees under state law to enjoin unsafe workplace conditions should be maintained under traditional principles of equity).

77. See Madison v. Phillips Petroleum Co., 88 F.2d 515, 519 (5th Cir. 1937), cert. denied, 301 U.S. 703 (1937) (object of warning is to allow for prevention); see Robinette v. Norfolk \& W.Ry. Co., 249 Ky. 93, 60 S.W.2d 344 (1933) (same).

78. See Traynor, Statutes Revolving in Common-Law Orbits, 17 CATH. U.L. REV. 401 (1968). Statutes were recognized as sources of common law in the nineteenth-century doctrine of the equity of statutes. See Landis, Statutes and the Sources of Law, in HARVARd LEGal EssaYs 213, 214-15 (R. Pound ed. 1934).

79. 29 U.S.C. $\$ \S 651-678$ (1976).

80. The Occupational Safety and Health Act was enacted "to reduce the number and severity of work-related injuries and illnesses which, despite current efforts of employers and government, are resulting in ever-increasing human misery and economic loss." S. REP. No. 1282, 91st Cong., 2d Sess. 1 , reprinted in [1970] U.S. CODE CONG. \& AD. NEWS 5177, 5177.

81. In 1973, for example, the Ciba-Geigy company in McIntosh, Alabama was required by an 
these decisions unions have been supplied with the generic names of all chemical substances used or produced in the employer's plant, toxicity and health effect information, monitoring data, and statistical data related to working conditions. ${ }^{82}$

A right to know analogous to that of the employee at common law has developed in the field of consumer transactions, first through the common law, in the tort of misrepresentation and the contract doctrine of implied warranty, and later through direct disclosure regulation. ${ }^{83}$ Federal legislation now requires standardized disclosure of material facts in major areas of consumer transactions. The Hazardous Substances Labeling Act, ${ }^{84}$ for example, requires the identification of toxic substances. Similar laws mandate the disclosure of standardized finance charge rates and other credit information in consumer credit sales and loan transactions, ${ }^{85}$ warnings that cigarette.smoking is hazardous to health ${ }^{86}$ specifications of fabric composition, ${ }^{87}$ and listings of the ingredients in certain packaged foods.

The consumer's right to know has developed partly in response to the information imperfections and hidden hazards created by complex production and marketing processes. ${ }^{89}$ Information-search costs by consumers are duplicative and prohibitively high and make standardized disclosure by sellers the most efficient solution to information market imperfections.90 By requiring more information rather than controlling products, disclosure laws affirm the right of individuals to free choice of personal utility.

Similar information imperfections exist in the workplace, which has

arbitration decision to furnish to Local 3-562 of the Oil, Chemical and Atomic Workers Union (OCAW) the chemical names of the hundreds of substances used in the plant, most of which had been known only by trade names or code numbers. D. BERMAN, supra note 3, at 191. In October 1977, in response to the discovery of sterility among OCAW pesticide workers exposed to dibromo chloropropane (DBCP), the OCAW directed its local unions to request from their employers detailed information about toxic exposures and morbidity statistics. NLRB decisions in Minnesota Mining \& Mfg. Co. \& OCAW Local 6-418, N.L.R.B. JD-124-79 (Minneapolis, March 13, 1979) and in Colgate Palmolive Co. \& OCAW Local 5-114, N.L.R.B. JD-(SF)-61-79 (Kansas City, March 27, 1979) upheld such requests under sections $8(a)(1)$ and $8(a)(5)$ of the NLRA, 29 U.S.C. $\$ \S 158(a)(1)$, $158(a)(5)(1976)$, as relevant and necessary to the unions' obligations to represent fairly and properly the employees in the bargaining unit. Minnesota Mining \& Mfg. Co. \& OCAW Local 6-418, N.L.R.B. JD-124-79 (Minneapolis, March 13, 1979), at 6.

82. Minnesota Mining \& Mfg. Co. \& OCAW Local 6-418, N.L.R.B. JD-124-79 (Minneapolis, March 13, 1979), at 18.

83. SEE D. RICE, CONSUMER TRANSACTIONS 330 (1975). The philosophy of caveat emptor that developed in the nineeteenth century, see id. at 4, has increasingly given way to the philosophy of "let the seller disclose." Mourning v. Family Publications Serv. Inc., 411 U.S. 356, 377 (1973).

84. 15 U.S.C. \$§ 1261-1274 (1976).

85. Consumer Credit Protection Act (Truth in Lending Act), 15 U.S.C. $\$ \S 1601-40$ (1976).

86. Gigarette Labeling \& Advertising Act of 1965, 15 U.S.C. \$ 1331-1340 (1976).

87. Labeling of Fur Products, 15 U.S.C. $§ 69$ (1976); Textile Fiber Products Identification, 15

U.S.C. $\$ 70$ (1976); Labeling of Wool Products, 21 U.S.C. § 68(b) (1976).

88. Federal Food, Drug \& Cosmetic Act, 15 U.S.C. $\$ 343$ (1976).

89. See D. RICE, supra note 83 , at 5 .

90. Id. at 331 . 
been transformed by a related increase in complexity and in the use of products with hidden dangers. In fact, disabled workers have sought compensation through product liability claims from manufacturers of workplace equipment, materials, or substances to supplement inadequate workers' compensation.$^{91}$ Employers, like sellers of hazardous products, have lower information costs than employees in assessing the risks specific to their workplaces, and through disclosure can enhance the ability of employees to contract for maximum personal utility.

On this common law basis, supported by analogy to consumer transactions law, employers should have the duty to disclose to employees all reasonably discoverable information regarding the identity and associated health risks of all toxic substances found in their workplaces. Gourts should issue injunctions requiring disclosure on a job position basis to any aggrieved employee or class of employees.

\section{Federal Right to Know Legislation}

Though the common law establishes an equitable basis for disclosure of health risks, neither it nor current state statutory approaches ${ }^{92}$ can facilitate the standardization necessary for competitive efficiency in risk reduction. Only federal legislation, coupled with increased federal expenditures on research, can achieve this standardization and further the objectives underlying the right to know.

Federal disclosure legislation based on the consumer protection model should require employers to obtain the best available information about the risks associated with substances to which employees are exposed and to disclose that information in a systematic way. The information should include the generic names of all chemicals used in the workplace, ${ }^{93}$ to al-

91. See Note, supra note 3, at 919-20. Some courts have imposed on manufacturers a duty to warn users and consumers, including those who use the manufacturer's products on the job. This manufacturer's duty is similar to the employer's common law duty to warn the employee. See RESTATEMENT (SECOND) OF TORTS $\S 402 A$, Comments j \& k (1965).

In Borel v. Fibreboard Prods. Corp., 493 F.2d 1076 (5th Cir. 1973), the court applied strict products liability doctrine to a case involving occupational disease. The plaintiff had been an insulation worker and had contracted asbestosis, a chronic lung disease resulting from inhalation of asbestos fibers. Finding the manufacturer liable for failure to warn, the court interpreted the seller's duty as "a responsibility to inform users and consumers of dangers which the seller either knows or should know at the time the product is sold," limited by what is "reasonably foresecable, or scientifically discoverable." Id. at 1088. The insulation manufacturer was held to the "knowledge and skill of an expert," including "at a minimum [that] he must keep abreast of scientific knowledge, discoveries, and advances and is presumed to know what is imparted thereby." Id. at 1089.

92. Current state statutes do not require standardized disclosure of the kind proposed here. See pp. 1798-99 supra. Economies of scale in the production of toxicological information make standardization through federal action much more feasible. See pp. 1808 infra.

93. The principal objection raised by employers to disclosure of the chemical identity of substances, the need to protect trade secrets, is valid only in limited circumstances. See Minnesota Mining \& Mfg. Co. \& OCAW Local 6-418, N.L.R.B. JD-124-79 (Minneapolis, March 13, 1979), at 13 
low independent assessment by employees and their representatives of substances whose toxicity is uncertain.94 Employers also should be required to describe any established health risks presented by each chemical at various exposure levels and to estimate the exposure levels in the workplace for each work position. ${ }^{95}$

Rather than requiring evaluation by individual employers, the act should require the National Institute for Occupational Safety and Health $(\mathrm{NIOSH})^{96}$ to assess the health risks posed by all toxic substances at various exposure levels and to maintain the standardized evaluations on a current basis." NIOSH should classify substances by the nature of the risk they pose, ${ }^{98}$ and should construct a dose response curve ${ }^{99}$ or other risk quantification for each hazardous substance. ${ }^{100}$

The required occupational health risk disclosures should be presented in an "occupational health impact statement." Every employer should be required to prepare the statement annually for distribution to all current and potential employees. By providing standardized information, occupational health impact statements would enable employees to compare the health risks posed by alternative workplaces and work positions. The statement's format also could be standardized to facilitate such comparison.

Private parties should be able to enforce right to know legislation by recovering substantial, fixed civil penalties for violations, without having

(trade secrets do not excuse employer from obligation to provide information relevant to Union's duty to bargain on behalf of employees); 45 Fed. Reg. 35,212, 35,217 (1980) (trade secret concerns accomodated only when not in conflict with purposes of disclosure).

94. The right to independent assessment is particularly important in the case of substances whose chemical structure has been altered slightly or recently.

95. This requirement need not result in added monitoring expenses for employers. NIOSH could provide tables of exposure estimates for standard industrial processes based on sample monitoring for use by employers who are not required to monitor and who choose not to do so. The employer who feels such estimates are too high would be free to undertake monitoring.

96. See note 10 supra.

97. NIOSH currently maintains The Registsy of Toxic Effects of Chemical Substances, see note 28 supra, which catalogs toxic substances and the level at which toxicity occurs.

98. For example, all substances for which a positive Ames test has been conducted but for which there is no other toxicological and no epidemiological evidence of carcinogenity might fall within one classification. The Ames test, developed by Professor Ames of the University of California at Berkeley, provides a quick indication of potential carcinogenity. L. AGRAN, supra note 50, at 64. OSHA's classification scheme for carcinogens, 45 Fed. Reg. 5002 (1980) (to be codified in 29 C.F.R. $\S 1990$ ) (classifying carcinogens into four categories), represents the kind of classificatory framework that could be used to establish standardized risk assessment.

99. Toxicological testing of substances given to animals in high dosages may establish a curve that indicates probable toxicity or carcinogenity at the lower dosage levels to which workers may be exposed. Epidemiological studies with complete data bases also could establish a relationship between statistical occurrence of disease (response) and levels of exposure (dose).

100. The average worker should be able to interpret quantitative risk assessment adequately. See 45 Fed. Reg. 35,212, 35,233 (1980). In the case of organized workers, expert interpretation may be available. 
to prove actual damages. ${ }^{101}$ Any employee or job offeree who does not receive an occupational health impact statement or who receives a false or incomplete statement should have a cause of action. Private enforcement is consistent with viewing disclosure as an individual, common law right, and would ensure effective disclosure without a massive expansion of federal inspection and prosecution resources.

The government should increase its role in the collection of toxicological and epidemiological information to take advantage of economies of scale in research on occupational health risks. The ultimate effectiveness of disclosure legislation will depend in large part upon the resources allocated to research and the quality of the resulting risk assessments. The current allocation of resources for occupational health research in general and for toxicological research in particular is much too small, especially in comparison with overall expenditures on cancer research. ${ }^{102}$

The proposed legislation would create a meaningful right to know in the context of occupational disease, and would make more just the distribution of health risks resulting from the use of industrial chemicals. Occupational health impact statements would permit more effective bargaining for safer workplaces and more accurate risk premiums. Such statements also would create a very complete data base for epidemiological studies. Finally, the imposition of civil liability would force employers to bear more fully the health costs of their enterprises and thus would encourage cost-effective alteration of production processes to reduce health risks.

\section{Conclusion}

By most accounts, current efforts to regulate occupational health and safety are ineffectual. ${ }^{103} \mathrm{~A}$ major obstacle to effective reduction of workplace health risks is the lack of information provided to those at risk. Cur-

101. A similar liability structure, including the award of reasonable attorneys' fees in successful actions, has been utilized in other federal disclosure legislation. See, e.g., $\S 130$ of the Truth in Lending Act, 15 U.S.C. $\S 1640$ (1976). Enforcement depends largely on "private attorney generals." See Ratner v. Chemical Bank N.Y. Trust Co., 329 F. Supp. 270, 280 (S.D.N.Y. 1971); Macey, Award of Attorney Fees as a Stimulant to Private Litigation Under the Truth in Lending Act, 27 BUS. LAW. 593 (1973). This enforcement mechanism also has been utilized in civil rights legislation. See, e.g., Title II of the Civil Rights Act of 1964, $\S 204$ (b), 42 U.S.C. $\S 2000 a-3$ (b) (1976) (reasonable attorneys' fees to prevailing party in discretion of court).

102. Epidemiological studies indicate that environmental factors cause from $70 \%$ to $90 \%$ of all cancers. See S. EPSTEIN, supra note 63, at 19. Yet only $6 \%$ of National Cancer Institute expenditures are devoted to chemical carcinogenesis, allowing for screening of about 50 of the 500 to 1,000 new substances that are developed each year. Job Diseases Unpublicized Threat, Obey Says in Accepting Steiger Award, [1979] O.S.H. REP. (BNA) 609 (statement of Rep. David R. Obey (D-Wis.) at American Conference of Government Industrial Hygienists mid-year symposium). See generally S. EPSTEIN, supra note 63, at 330-34 (analysis of National Cancer Institute budget priorities).

103. See, e.g., D. BERMAN, supra note 3, at 33-36 ("Five years of OSHA have led to few improvements in working conditions."); Nichols \& Zeckhauser, supra note 54, at 39 (OSHA's performance "has become a prominent symbol of misguided Federal regulation"). 
rent statutory and regulatory approaches have not dealt adequately with this information problem. Equitable enforcement of the employer's common law duty to warn employees will help to remedy this inadequacy, but legislation requiring standardized disclosure is needed to support fully the right of workers to protect their own health. Great potential remains for effective self-regulation by an informed workplace population. ${ }^{104}$ As OSHA has recognized, "[s]ound public policy dictates that workers be afforded a central role in the detection and solution of health problems, as there are no assurances that anyone else will protect their health with equal vigor or determination." 105

104. See Marshall Details Labor Department Plan to Evaluate Labor-Management Committees, [1980] O.S.H. REP. (BNA) 3 (discussing Labor Department evaluation of possible incorporation of labor-management committees into its occupational health and safety strategy); Safety/Health Committees, Bargaining Seen as Growing Factors in Regulation, [1980] O.S.H. REP. (BNA) 597 (Morris Davis, executive director of labor occupational health program, University of California at Berkeley, arguing that labor-management committees and bargaining are growing forces in workplace regulation).

105. 45 Fed. Reg. $35,212,35,213$ (1980). 